\title{
On the acidity and salinity of rain
}

\author{
Evilue Gorha M \\ Freshwater Biological Association, The Ferry House, Ambleside, Westmorland
}

(Received 26 Januar: 1955)

ABSTRACT

Analyses of $\mathrm{pH}, \mathrm{Na}, \mathrm{K}, \mathrm{Ca}, \mathrm{Mg}, \mathrm{HCO}_{3}, \mathrm{Cl}, \mathrm{SO}_{4}, \mathrm{NO}_{3}$, and $\mathrm{PO}_{4}$ are recorded for forty-two rain samples collected in the English Lake District between 14 May and 23 October 1954.

$\mathrm{TaCl}$ was often an important constituent, and the main source of $\mathrm{Na}, \mathrm{Mg}$, and $\mathrm{Cl}$ appeared to be sea-spray. $\mathrm{SO}_{4}$ was clearly correlated with soot, and free $\mathrm{H}_{2} \mathrm{SO}_{4}$ frequently accounted for an appreciable proportion of total ions. $\mathrm{Ca}, \mathrm{K}$, and $\mathrm{SO}_{4}$ were correlated to some extent. $\mathrm{HCO}_{3}$ was absent from more than half the samples. $\mathrm{NO}_{3}$ and $\mathrm{PO}_{4}$ were usually low in concentration. Sea-spray influence appeared greatest in autumn, while industrial pollution reached its highest concentration in spring.

The ecological significance of the ions in rain is pointed out.

\section{INTRODUCTION}

Although the geochemical importance of rain has long been emphasized, its ionic composition has seldom been investigated except for $\mathrm{Cl}, \mathrm{SO}_{4}, \mathrm{NO}_{3}$, and $\mathrm{NH}_{4}$ (ErIKssor, 1952). This paper presents six months' analyses for $\mathrm{pH}, \mathrm{Na}, \mathrm{K}, \mathrm{Ca}$,. $\mathrm{Mg}, \mathrm{HCO}_{3}, \mathrm{Cl}, \mathrm{SO}_{4}, \mathrm{NO}_{3}$, and $\mathrm{PO}_{4}$ at a site in the English Lake District.

THe AREA

Samples were collected between 14 May and 23 October 1954 at Wise Een Tarn on Claife Heights, above the western shore of Windermere and about 50 kilometres east of the Irish Sea. Rainfall is highly variable in this region of marked relief. At Ferry House and Wraymires Hatchery, just east and west of Claife Heights, the range is between about 150 and 200 centimetres per year. Monthly fall is about

- 10 centimetres in spring, rising to $15-18$ centimetres in autumn and winter. Southwesterly winds prevail.

\section{METHODS}

Rain was sampled by a polythene funnel 30 centimetres. in diameter, surrounded by short stainless-steel wires for protection against.birds (EGirer et al., 1949), and leading to a gallon polythene bottle. Whatman-541 filter papers (washed with distilled water) were tied over the end of the funnel to trap soot and insects, and were replaced after each collection. Samples averaged about 2 litres, and ranged from 0.7 to 4.5 litres. They were stored in polythene bottles.

$\mathrm{pH}$ was measured by glass electrode; $\mathrm{Na}$ and $\mathrm{K}$ by EEL flame photometer with Calor-gas fuel; $\mathrm{Ca}$ and $\mathrm{Mg}$ by versenate titration; $\mathrm{HCO}_{3}$ by titration to a methyl $\mathrm{red} /$ bromocresol green end point buffered at $\mathrm{pH} 4.5$; and $\mathrm{Cl}$ and $\mathrm{SO}_{4}$ conductimetrically after ion-exchange treatments, using a method derised in this laboratory by F. J. MACKereth (in press). $\mathrm{NO}_{3}$ was estimated by visual colorimetry with phenol-disulphonic acid, adding excess $\mathrm{CaCO}_{3}$ before evaporation to neutralize the rain-acids. $\mathrm{PO}_{4}$ was also determined by risual colorimetry, employing the usual ammonium molybdate/stannous chloride technique. A rough inder to soot was obtained by grading the blackness of the filters from 0 to 5 and dividing by sample volume in litres. 


\section{Total Ions}

Fig. 1 shows the modal concentration of total ions to have been slightly more than $0 \cdot 1$ milli-equivalents per litre. In rains of this concentration $\mathrm{SO}_{4}$ usually exceeded $\mathrm{Cl}$; at the higher levels $\mathrm{Cl}$ was the dominant anion. If anion and cation values for the entire period (see Table 1) are summed, the former amount to 0.165 and the latter to $0 \cdot 155$ milli-equivalents per litre. The slight excess of anions, much less in autumn than in spring and summer, would be balanced to some degree by $\mathrm{NH}_{4}$.

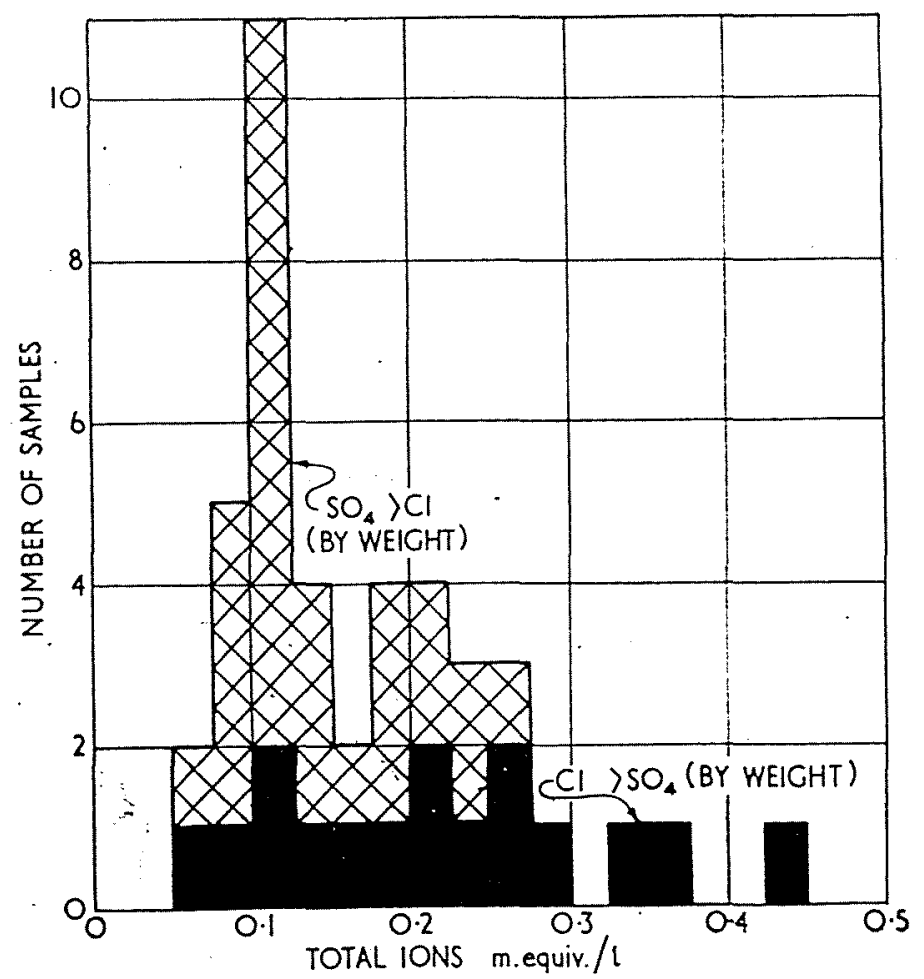

Fig. 1. Frequency distribution of total ion concentrations in Lake Pisirict rains.

Dissolred $\mathrm{NO}_{3}$ and $\mathrm{PO}_{4}$ usually made a negligible contribution to total ions. $\mathrm{NO}_{3}-\mathrm{N}$ was less than 0.02 parts per million in the majority of samples, most of the higher values being encountered in spring. $\mathrm{PO}_{4}-\mathrm{P}$ was below 0.001 parts per million in thirty-eight of forty-two samples.

Ion concentrations similar to or little greater than those of rain have been observed in pools on raised or blanket bogs in northern Britain (GokHAM, in preparation), and in many upland tarns of the Lake District (F. J. MACKERETH andJ. HERoN, private communication). Atmospheric precipitation must therefore be the principal source of nutrients for their plankton. As to the larger lakes. Windermere itself has only 0.5 milli-equivalents of total ions per litre. three times the concentration in rain. Its ionic proportions are of course very different, with Ca and $\mathrm{HCO}_{3}$ the dominant ions.

\section{Sodium, Magsesium, ind Chloride}

$\mathrm{Na}$ and $\mathrm{Mg}$ are examined in relation to $\mathrm{Cl}$ in Figs. 2 and 3, the straight lines representing the proportions in sea-water. The close correspondence strongly suggests derivation almost entirely from sea-spray: it may be remarked that the two highest $\mathrm{NaCl}$ values followed the two heariest gales from the sea. Mechanisms 
of sea-salt entry into the atmosphere have recently been much discussed (BOYCE, 1951; WoodCoch et al., 1953; KNelman et al., 1954; Kievtzler et al., 1954; BLATCHARD, 1954).

In most Lake District tarns and lakes $\mathrm{Na}$ and $\mathrm{Cl}$ are likewise present in proportions similar to that of sea-water, so that rainfall - and hence sea-spray-may be inferred as the chief source.

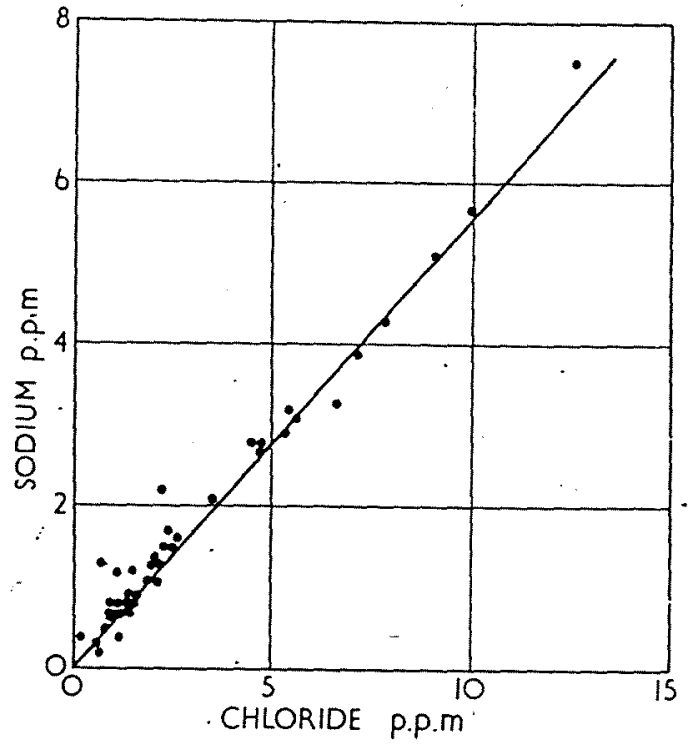

Fig. 2. The relation between sodium and chloride in Lake District rains. Straight line $=$ proportion in sea-water.

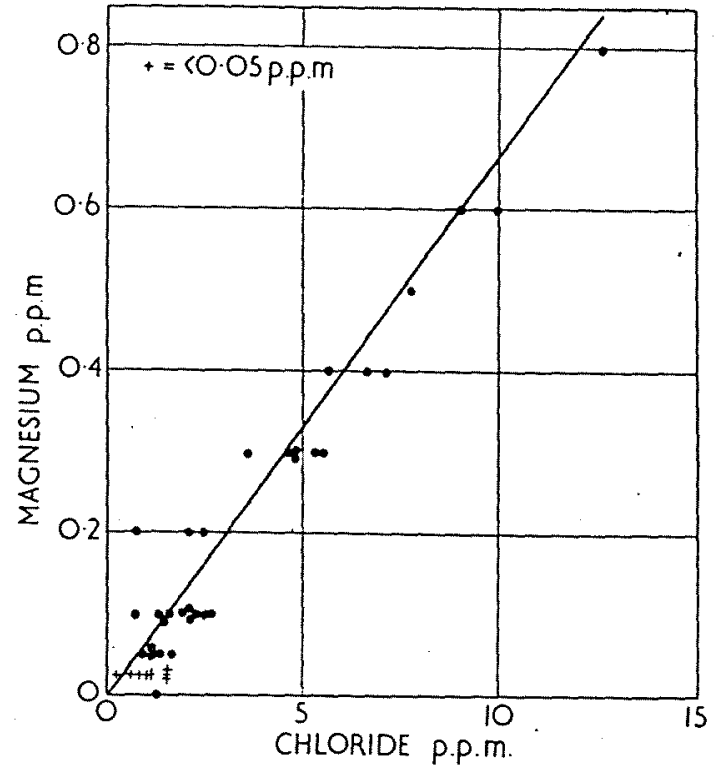

Fig. 3. The relation between magnesium and chloride in Lake District rains. Straight line $=$ proportion in sea-water.

Even the rain highest in $\mathrm{NaCl}$ may not have derived its whole ion content from the sea. The ratios of $\mathrm{H}$-ions and $\mathrm{HCO}_{3}$ to $\mathrm{Cl}$ were far higher than in sea-water, and the ratio $\mathrm{K}: \mathrm{Cl}$ was half as high again in this rain as in the sea. The ratios $\mathrm{SO}_{4}: \mathrm{Cl}$ and $\mathrm{Ca}: \mathrm{Cl}$ were also slightly high. Alternative hypotheses might, however, be invoked. Japanese workers (Koyama and SUGAWARA, 1953) have postulated a differential separation of atmospheric salts by rain, hygroscopic chloride particles being washed out most easily and quickly. And CoNwAY (1942) has inferred a supply of $\mathrm{SO}_{4}$ by diffusion of $\mathrm{H}_{2} \mathrm{~S}$ from the muds of the continental shelf, which might perhaps account for a small amount of $\mathrm{H}_{2} \mathrm{SO}_{4}$ in rain from the sea.

The concentrations of $\mathrm{Na}, \mathrm{Mg}$, and $\mathrm{Cl}$ rose during the period studied, particularly in autumn. Preliminary examination of wind-speeds and directions has so far offered no clear explanation. It is hoped to investigate the matter further.

\section{Soot, Sulphate, and Hydrogen Iors}

Fig. $t$ shows $\mathrm{SO}_{4}$ plotted against $\mathrm{Cl}$. While individual rains were often low in both ions, none was high in both, indicating that $\mathrm{Cl}$ and $\mathrm{SO}_{4}$ came from different sources. Sea-spray has been suggested as the origin of the former, and must necessarily supply some $\mathrm{SO}_{4}$ as well. Howerer, a large amount of the latter ion appears to come from atmospheric pollution, as shown in Fig 5-where $\mathrm{SO}_{4}$ is plotted versus soot index. Five samples with very little soot contamination (see Table 3 ) yielded an arerage of 1.7 parts per million of $\mathrm{SO}_{4}$; all but one of the ten sootiest rains had 


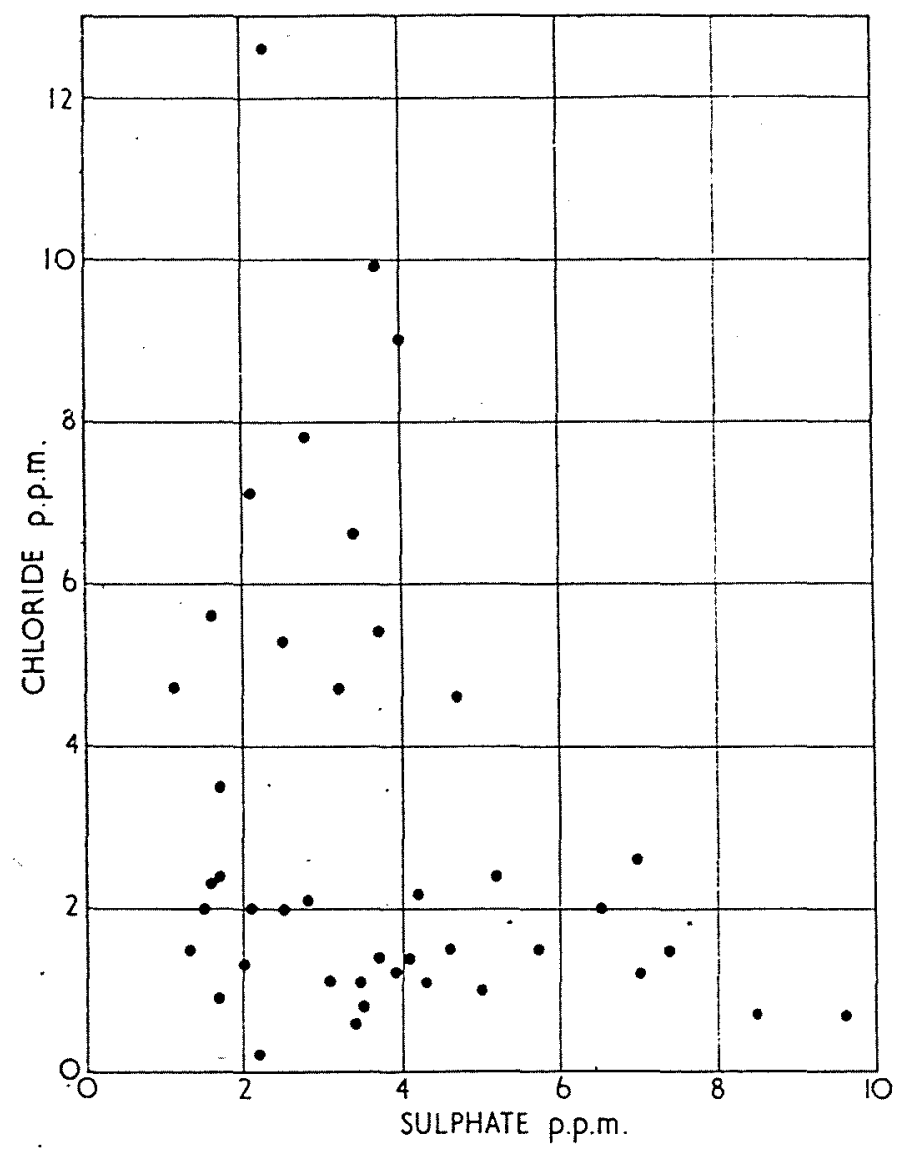

Fig. 4. Sulphate and chloride in Lake District rains.

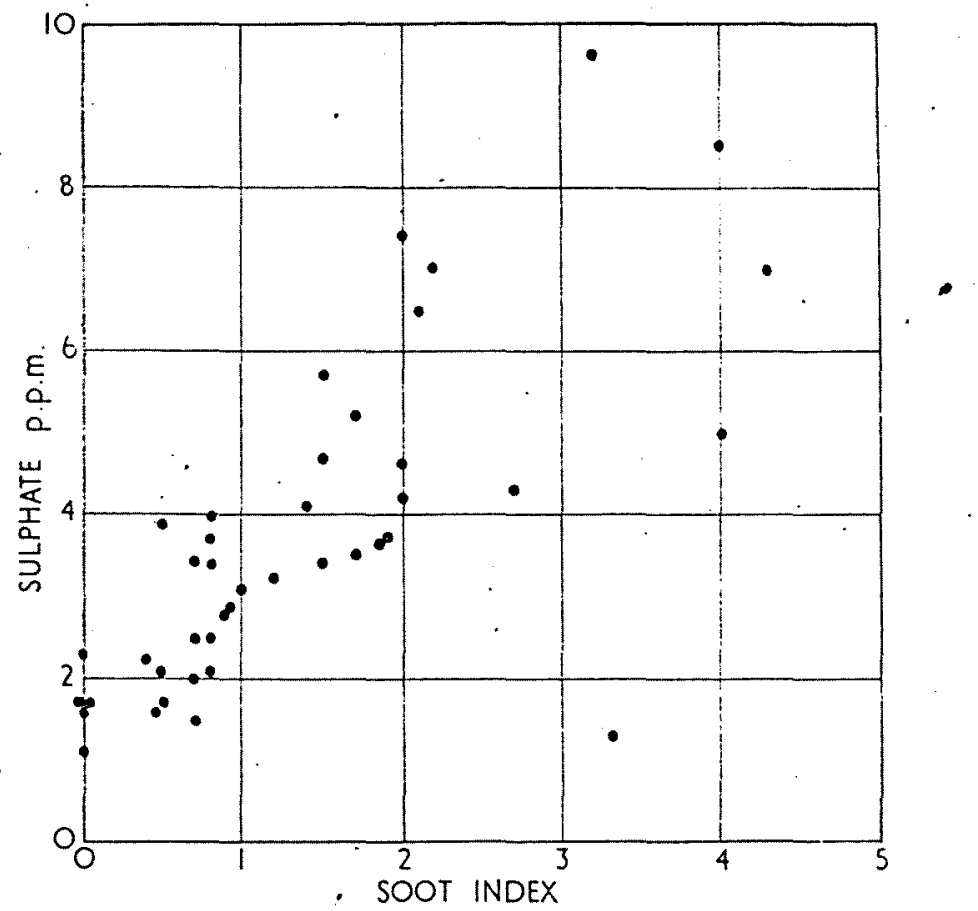

Fig. 5. The relation betreen sulphate and soot in Lake District rains. 
more than four parts per million. It may be noted that filter contamination was always very black; on no occasion did a brown soil coloration prevail.

Fig. 6, illustrating a correlation between $\mathrm{SO}_{4}$ and $\mathrm{H}$-ion concentration, demonstrates that $\mathrm{H}_{2} \mathrm{SO}_{4}$ may be a substantial component of Lake District rains. The straight line represents equivalent proportions of the two ions. While pitting of building stone in industrial cities is well known, the writer has encountered in the

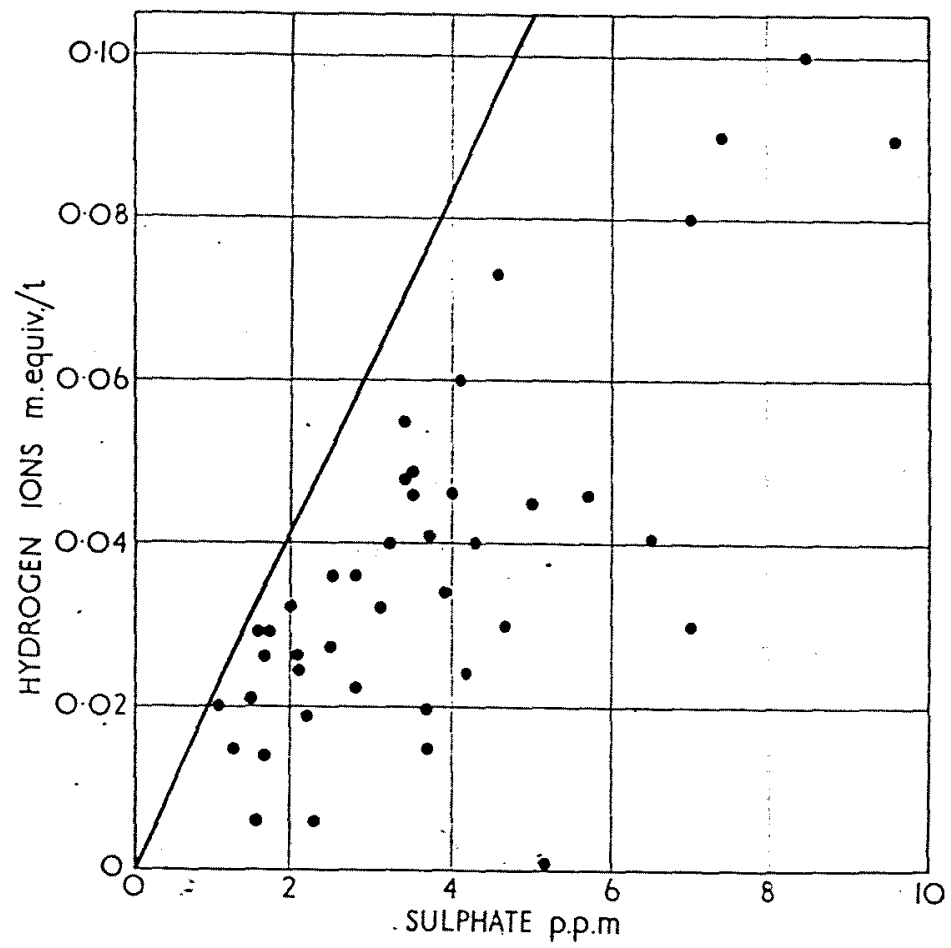

Fig. 6. Sulphuric acid in Lake District rains. Straight line = equivalent proportions of sulphate and hydrogen ions.

literature very little eridence of free mineral acid in country rain. CoxwaY (1942) speculates that acids produced by oxidation of sulphur compounds may react with most or all of the bicarbonates deriving from dust or ash in the rain. In contrast, TAMm (1953) gives a $\mathrm{pH}$ range of $4 \cdot 3-5.9$ for rain in open fields in east Sweden, but no anion analyses.

Such a supply of dilnte mineral acid must be an appreciable factor in rock and soil weathering, especially where vegetation is sparse. Horeover, if soot is the main source, its influence must have increased enormously during the past century, and be still growing. As to vegetation, two somewhat antithetical effects may be postulated. Bathing with dilute $\mathrm{H}_{2} \mathrm{SO}_{4}$ may well be inimical to many species. On the other hand, the addition of extra $\mathrm{Ca}$ and $\mathrm{K}$ in the rain, and in particular an increased degree of weathering, may lead to greater nuirient supply. Thile upland tarns owe most of their acidity to rain, which enters them chiefly as superficial run-off, they may also receive added $\mathrm{Ca}$ and $\mathrm{K}$ from atmospheric pollution. Lowland waters may also obtain more nutrients due to neutralization of rain-acids by bases from soil and rock minerals.

Although soot and $\mathrm{SO}_{4}$ decrease from May to October, acidity raries rather little and is gireatest in summer, because of an eren larger decrease in $\mathrm{Ca}$ and $\mathrm{K}$ from the first to the middle period (see Table 1). 
Comparison of the present data with figures for atmospheric precipitation in industrial cities should be of much interest. Table 2 gires analyses for $\mathrm{pH}, \mathrm{Ca}, \mathrm{Cl}$. and $\mathrm{SO}_{4}$ in rain subject to extreme industrial contamination. That the acidity is lower than in Lake District rains, despite a lower rainfall, is especially noteworthy. Furthermore, $\mathrm{Cl}$ is about half as much as $\mathrm{SO}_{4}$ in city rain, while in the sootiest Lake District samples the concentrations of $\mathrm{SO}_{4}$ were usually several times those of $\mathrm{Cl}$. Such dissimilarity of proportions suggests a differential separation of the components of industrial pollution. Another possibility might be oxidation of sulphides in soot to $\mathrm{H}_{2} \mathrm{SO}_{4}$ while in the atmosphere. In this connection, black soot collected above a grate in which no fire had been lit for two or three weeks gave a strong odour of $\mathrm{H}_{2} \mathrm{~S}$ upon acidification.

The regression of $\mathrm{SO}_{4}$ on $\mathrm{Cl}$ in Lake District tarns and lakes shows a proportionality markedly similar to the mean $\mathrm{SO}_{4}: \mathrm{Cl}$ ratio in rain. It may be supposed that atmospheric precipitation is the main source of both ions.

Table 1. Ion concentrations in Lake District rain

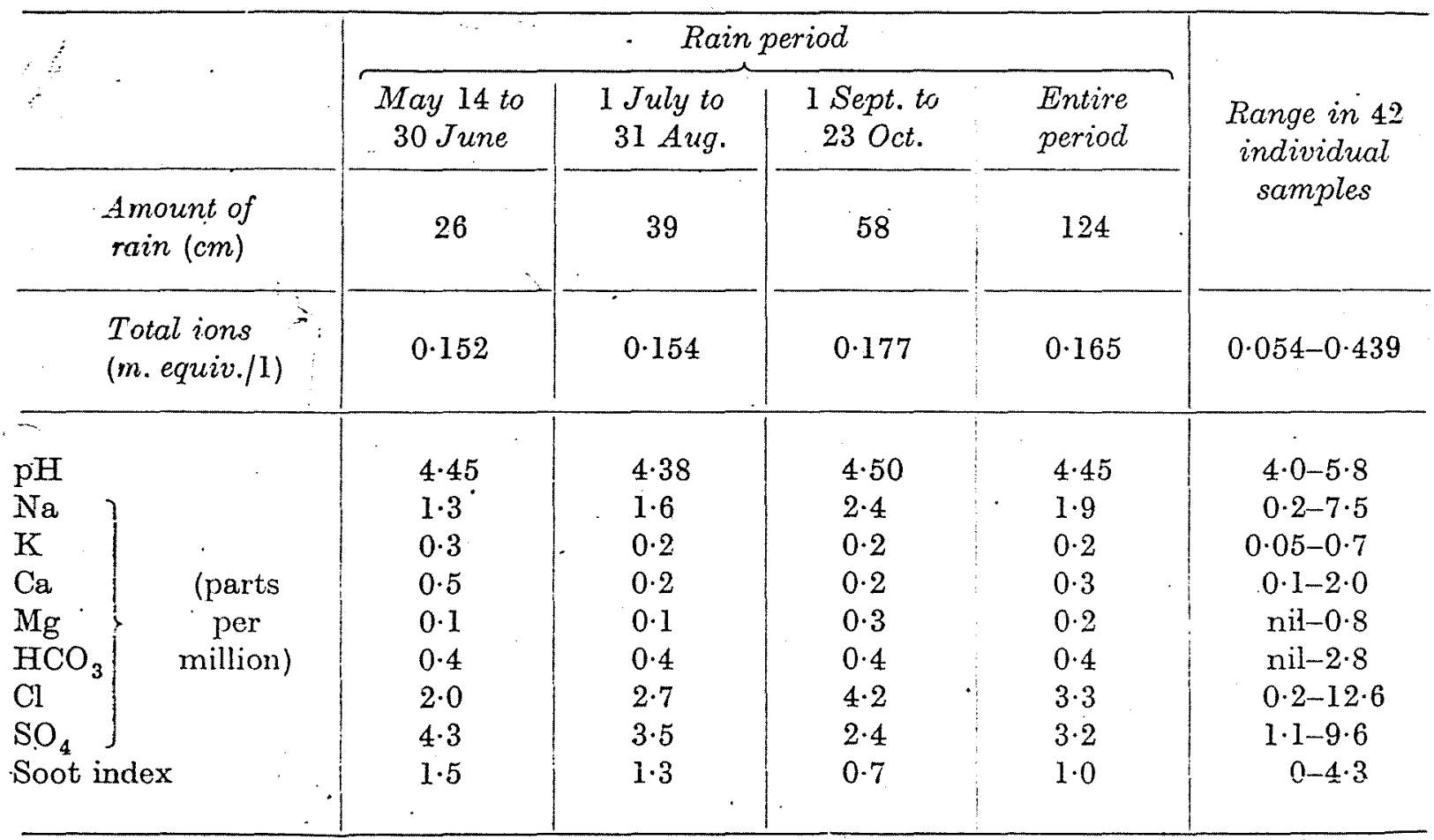

Calcium, Potassium, axd Bicarbonate

Fig. 7 reveals some correlation between $\mathrm{Ca}$ and $\mathrm{SO}_{4}$; while Fig. 8 shows a rise in the upper limit for $\mathrm{K}$ with increasing $\mathrm{SO}_{4}$ concentration. Fig. 9 further demonstrates that these two cations follow generally similar trends. While many of the sootiest rains had no more $\mathrm{Ca}$ and $\mathrm{K}$ than the purest, the highest concentrations were distinctly limited to the more contaminated samples: notably in spring. Perhaps the relatively dry spring. weather, following a winter of fuel-burning, builds up atmospheric pollution at this time.

At any given $\mathrm{SO}_{4}$ level, rains with $\mathrm{HCO}_{3}$ naturally contain more $\mathrm{Ca}$ and $\mathrm{E}$, since $\mathrm{Na}$ and $\mathrm{Mg}$ are commonly balanced by $\mathrm{Cl}$. The source of these bicarbonates may be industrial, agricultural, or natural (i.e., soot or ash, fertilizer or dust from 
cultivated fields, or dust from uncultivated ground). The highest $\mathrm{Ca}$ value, two parts per million, lay well above the normal regression of $\mathrm{Ca}$ on $\mathrm{SO}_{4}$ : due presumably to an abnormal local supply of $\mathrm{CaCO}_{3}$ to the atmosphere from one of these sources.

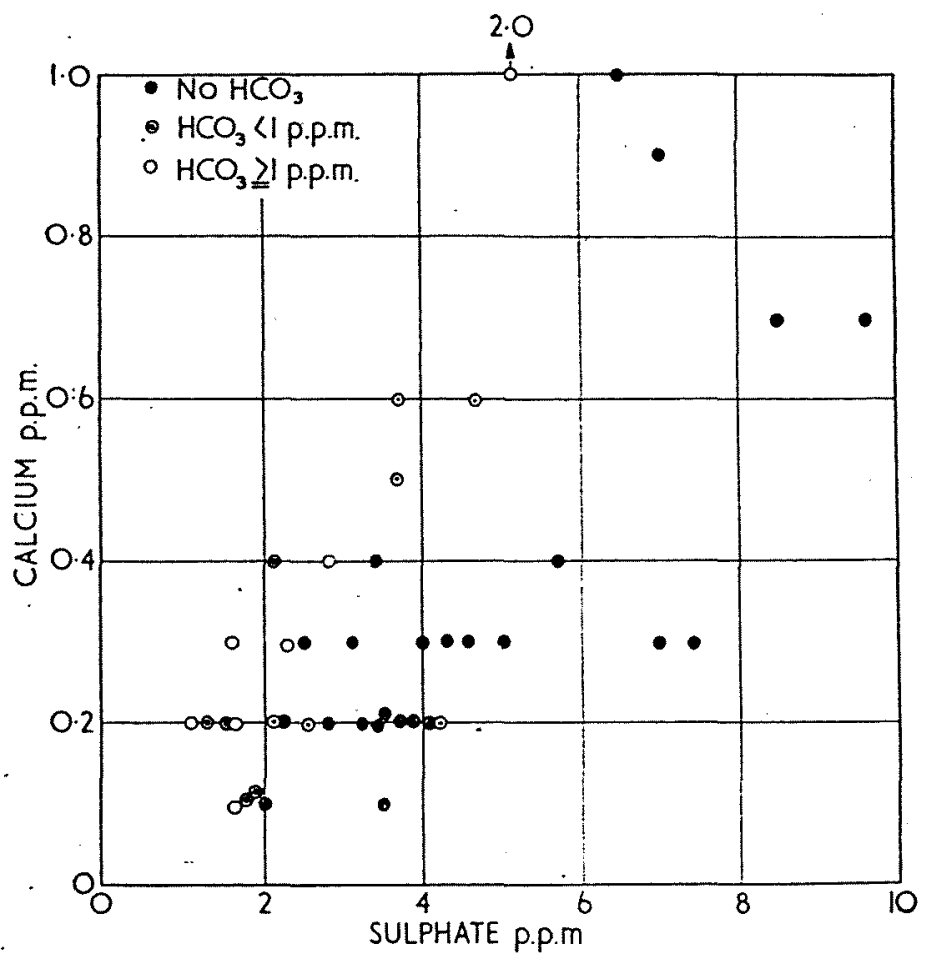

Fig. 7. Sulphate and calcium in Lake District rains with or without bicarbonate.

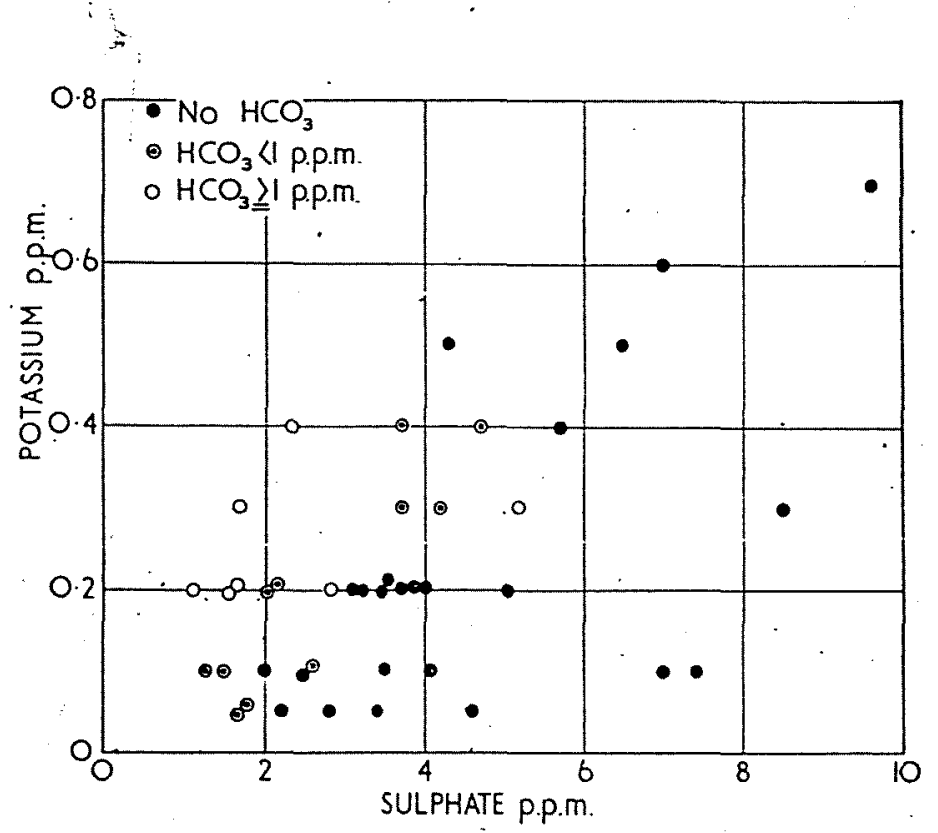

Fig. S. Sulphato and potassium in Lake District rains with or without bicarbonate.

- The ratio of $\mathrm{Ca}$ to $\mathrm{SO}_{4}$ is much higher in city rains (see Table 2) than in the sootiest of the present series.. Again, this may signify differential separation of atmospheric salts, or a gradual $\mathrm{H}_{2} \mathrm{SO}_{4}$ production from drifting soot.

Rain may be an important source of $\mathrm{K}$ for many natural bodies of water in the Lake District, in which it makes up only a small proportion of total dissolved ions. 
The median $\mathrm{K}$ : Cl ratio for tarns and lakes is in fact somewhat less than for the present rain series. In this connection it should be borne in mind that $\mathrm{K}$ is subject not only to a much stronger biological demand than $\mathrm{Cl}$, but also to fixation in nonexchangeable form by soil colloids.

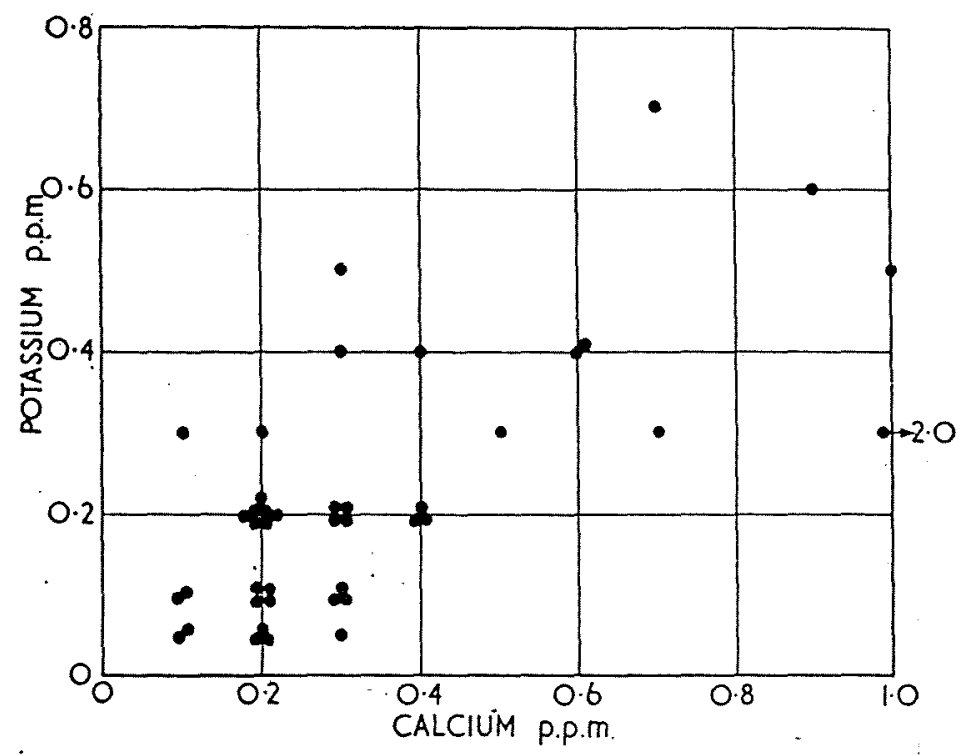

Fig. 9. The relation between calcium and potassium in Lake District rains.

Table 2. Ion concentrations in atmospheric precipitation over industrial cities (Leeds, London, Manchester, Sheffield, Glasgow, and Newcastle, 1944-49)*.

\begin{tabular}{|c|c|c|c|c|}
\hline \multirow{2}{*}{$\begin{array}{l}=\text { Rain } \\
(\mathrm{cm} / \mathrm{yr})\end{array}$} & \multirow{2}{*}{$p H$} & $C a$ & $C l$ & $\mathrm{SO}_{4}$ \\
\hline & & \multicolumn{3}{|c|}{ (parts per million) } \\
\hline 73 & 4.8 & $5 \cdot 8$ & 10.9 & 20.6 \\
\hline
\end{tabular}

\section{Composition of Soot-fRee RaIN}

Table 3 presents data for fire rain samples on whose filters only faint traces of soot were discernible. One of these was collected after a gale from the sea. The others, while obtained after or during fairly high winds, were not exceptionally rich in $\mathrm{NaCl}$, although it was the dominant component. $\mathrm{H}$-ions, $\mathrm{HCO}_{3}, \mathrm{Ca}, \mathrm{K}$, and $\mathrm{SO}_{4}$ were present in much more than the proportions of sea-water (relative to $\mathrm{NaCl}$ ). Part of the $\mathrm{SO}_{4}$ may have originated, as previously noted, from $\mathrm{H}_{2} \mathrm{~S}$ diffusing out of the muds of the continental shelf (CONWAY, 1942).

$\mathrm{H}_{2} \mathrm{SO}_{4}$ was much lower, and $\mathrm{HCO}_{3}$ much higher, than in sooty rains. At the same time $\mathrm{Ca}$ and $\mathrm{K}$ were in general lower in the clean rains, which makes it unlikely that the relatively high winds brought into the atmosphere more than the usual a mount of soil-dust, rich.in $\mathrm{CaCO}_{3}$ and $\mathrm{K}_{2} \mathrm{CO}_{3}$. Rather it would seem that the light soot particles were more widely dispersed than usual, or settled out more

* Data provided through the courtesy of D. MacDovgall, Chief Chemist, Fuel Research Station, Department of Scientific and Industrial Research. 
slowly-so that the $\mathrm{HCO}_{3}$ derived from soil particles was not neutralized by $\mathrm{H}$-ions from soot.

Table 3. Ion concentrations in five sool-free rains

\begin{tabular}{|c|c|c|c|}
\hline & & Mean & Range \\
\hline $\mathrm{pH}$ & & $4 \cdot 8$ & $4 \cdot 5-5 \cdot 2$ \\
\hline $\mathrm{Na}$ & & $3 \cdot 1$ & $1 \cdot 5-7 \cdot 5$ \\
\hline $\mathrm{K}$ & & $0 \cdot 2$ & $0.05-0.4$ \\
\hline $\mathrm{Ca}$ & (parts & $0 \cdot 2$ & $0 \cdot 1-0.3$ \\
\hline $\mathrm{Mg}$ & per & $0 \cdot 3$ & $0.05-0.8$ \\
\hline $\mathrm{HCO}_{3}$ & million) & $1 \cdot 2$ & $0 \cdot 5-2 \cdot 2$ \\
\hline $\mathrm{Cl}$ & & $5 \cdot 1$ & $2 \cdot 3-12 \cdot 6$ \\
\hline $\mathrm{SO}_{4}$ & & $1 \cdot 7$ & $1 \cdot 1-2 \cdot 3$ \\
\hline
\end{tabular}

Acknowledgments-My thanks are due to A. Wruson for collecting the samples, and to $J$. Heron for the $\mathrm{NO}_{3}$ and $\mathrm{PO}_{4}$ analyses. $\mathrm{I}$ am greatly indebted to my colleagues, F. J. Mackereth and J. Heron, not only for advice concerning the analytical techniques; but also for much helpful discussion of the results, and especially for placing at my disposal their unpublished analyses of almost two hundred tarns and lakes in the Lake District. The Chief Chemist of the Fuel Research Station of the Department of Scientific and Industrial Research, D. MaCDodgall, kindly provided the data on atmospheric precipitation in industrial cities.

\section{REFERENCES}

Blanchard, D. C. (1954) Nature, Lond. 173, 1048.

Boyce; S. G. (1951) Science 113, 620.

Conway, E. J. (1942) Proc. R. Irish Acad., Ser. B, 48, 119.

Egner, H., Eriksson, E., and Exlanumlsson, A. (1949) LantbrHögsi. Ann. 16, 593.

Eriksson, E. (1952) Tellus 4, 280.

Kientzler, C. F., Arons, A. B., Blanchard, D. C., and Woodcock, A. H. (1954) Tellus 6, 1. Knelman, F., Dombrowski, N., and Newite, D. M. (1954) Nature, Lond. 173, 261.

Koyama, T., and Sugawara, K. (1953) Bull. Chem. Soc. Japan 26, 123.

TAMM, C. O. (1953) Medd. Skogsforskn Inst: Stockh. 43, 1.

Woodcock, A. H., Krentzler, C. F., Arons, A. B., and Blanchard, D. C. (1953) Nature, Lond. 172, 1144. 